\title{
MEASURING THE SUPPORT FOR DEMOCRACY IN NAMIBIA \\ Intrinsic or Instrumental?
}

\author{
Lesley Blaauw \\ Dr Blaauw is a lecturer in the Department of Political and Administrative \\ Studies at the University of Namibia \\ Private Bag 13301, Windhoek, Namibia \\ Tel: + 264612063339 \\ e-mail:lblaauw@unam.na
}

\begin{abstract}
This paper argues that the notion of liberal democracy is inadequate in explaining the challenges faced by the Namibian government in its attempts to consolidate democracy. The contention is that political freedoms gained, such as free elections, a respect for human rights, and equality before the law are, inter alia, crucial to endowing the political regime in Namibia with legitimacy. For democracy to be truly consolidated in the country, however, these intrinsic elements must be complemented by an instrumental component. Simply put, political freedoms must be supported by economic delivery. Ultimately, the paper postulates that people measure their support and satisfaction with democracy holistically, hence the distinction between economic and political support becomes blurred.
\end{abstract}

\section{INTRODUCTION: \\ CONVENTIONAL CONCEPTS OF DEMOCRACY}

The notion of democracy is socially constructed. Although we may be able to agree broadly on the elements that constitute the concept we may not expect to reach agreement on its meaning and proper application in a lived social context. As such, the concept invariably invokes heated debate because it involves ongoing social and political processes which aim to maintain political rights and, at the same time, improve the socio-economic well-being of the people.

The latter is necessary because economic inequalities and severe poverty may threaten democracy, its institutionalisation and consolidation. The most basic requirement for a country to be considered a democracy is that citizens be 
empowered to choose and remove leaders. Thus, democracy is defined as a form of political regime in which citizens choose, in competitive elections, the occupants of top political office.

Such a concept of democracy is, however, minimalist. Writing on Africa in general, Wiseman (1999) asserts that a minimalist concept of democracy includes the introduction of democratic constitutions, the formation of political parties, comparatively free media, and the conduct of elections in a climate that can be described as relatively free and fair. The introduction of competitive elections is a critical precondition for the establishment of democracy but the institutionalisation of electoral competition is insufficient to consolidate democracy. Simply put, these values are of critical importance for the transition to democracy, but inadequate for its sustenance. A maximalist concept of democracy should cater for dimensions beyond its electoral form.

This paper will focus on two definitions of democracy that are often invoked during debates on the subject in Africa in general. Given the fact that the concept of democracy on the continent is often reduced to elections, ${ }^{1}$ a good entry point would be to define embedded liberal democracy.

Embedded liberal democracy as the defining element of electoral democracy consists of five partial regimes: 'a democratic electoral regime, political rights of participation, civil rights, horizontal accountability, ${ }^{2}$ and the guarantee that effective power to govern lies in the hands of democratically elected representatives' (Merkel 2004, p 36). This definition refers to the intrinsic or political value of democracy. Such a concept is, however, inadequate in a number of respects. For instance, the political right of participation cannot produce political equality in the face of extreme socio-economic inequality.

To be sure, the unequal distribution of economic resources has a negative impact on democracy because it puts the poor at a disadvantage in exercising their civil and political rights. In this equation the definition of democracy does not bring into relief a fair distribution of economic goods or social justice. Thus, as a normative project the 'democratic deficit' of this definition of democracy lies in its inability to 'deliver' economic and social requisites. For democracy to become embedded in the lives of ordinary people it will have to be broadened to meet

1 Wolgang Merkel (2004, p 34) asserts that 'Electoral democracy merely entails that the elections of the ruling elite be based on the formal, universal right to vote, such that elections are general, free and regular.' The problem with this concept is that the fairness of democratic elections is difficult to ascertain. Hence, the term electoral democracy is not particularly analytically useful.

2 For Merkel (2004, p 41) ‘Horizontal accountability of power concerns the structure of power. The term includes lawful government action checked by the division of power between mutually interdependent and autonomous legislative, executive and judiciary bodies.' In short, it refers to a system of checks and balances among and between government branches. 
their basic needs. In other words, we need an instrumental understanding of the notion of 'democracy'.

The notion of social democracy is particularly relevant to such an instrumental understanding. For democracy to be successful it must address the vexed question of economic rights and social justice. Simply put, democracy as a developmental ideology must provide for people's basic needs such as access to food, housing, medical care, and a clean environment. Ake (1993, p 241) argues that:

... for African democracy to be relevant and sustainable it will have to be radically different from liberal democracy... it will have to deemphasize abstract political rights and stress concrete economic rights, because the demand for democracy in Africa draws much of its impetus from the prevailing economic conditions within. Ordinary Africans do not separate political democracy from economic democracy or for that matter from economic-well-being.

This implies that 'Democracy is depicted as a distributive socio-economic order and among its substantive benefits are growing economic growth, socio-economic equity, and the provision of public services' (Keulder 2002, p 5). In other words, the value of democracy is seen to be instrumental, because it concerns itself with, among others, issues such as the alleviation of poverty and the improvement of living standards. This reinforces the social right of democracy, namely, the right to physical well-being.

To achieve this, political freedoms must be supported by effective economic delivery. Van de Walle (2002, p 75) posits that '... strong economic performance facilitates peaceful movement toward greater democracy' (also see Bratton \& Mattes 2001, p 451). Moreover, strong economic performance also increases the legitimacy of regimes and contributes to political stability. This reinforces the argument that 'successful development depends on a political and institutional environment that aligns the political incentives facing governments with the requirements of economic growth and improved social welfare' (Alence 2004, p166). A threat to sustainable human development, on the contrary, might occur 'where governments' incentives are at odds with developmental imperatives, policymaking and implementation are vulnerable to economically damaging opportunism' (Alence 2004, p166). This suggests that a broader definition of democracy should cater for both intrinsic and instrumental values. To achieve this, emphasis should not only be placed on the enjoyment of civil liberties, the state must also assume a particular developmental posture.

The resolution of the above apparently mutually exclusive projects has profound implications for the prospects of consolidating democracy in Namibia. 
Resolving the discourse surrounding the intrinsic versus instrumental value of democracy requires first and foremost posing and answering the question: What does the notion of democracy mean for ordinary Namibians, and how does this correspond with the literature review? One of the ways in which democracies are evaluated is by looking at democratic attitudes.

\section{THE MEANING OF DEMOCRACY IN NAMIBIA}

A literature review of the concept of democracy in Namibia reveals a common thread: that the edifice of Namibia's democracy is underpinned by liberal precepts (Good 2001; Tsie 2001; Southall, 2003). As such, democracy is most commonly associated with procedures to guarantee political competition and political participation. Schmitter \& Karl (1996, p 50) conceive democracy which caters for the above as 'a system of governance in which rulers are held accountable for their actions in the public realm by citizens, acting indirectly through the competition and cooperation of their elected representatives' (see also Huntington 1991, p 7). This definition suggests that democracy as a process finds expression in electoral politics. Bratton \& Mattes (2001, p 451) remind us that ‘Democracy ... is a system of rules and procedures by which leaders, groups and parties compete for power, and in which free and equal people elect representatives to make binding decisions.' State legitimacy, in this trajectory, depends on the consent of the governed. This suggests that the most basic requirement for democracy in Namibia is that citizens be empowered to choose and remove leaders. This represents the most common tenet upon which liberal democracy is premised.

Ake (2003, p 10) maintains that

Liberal democracy is markedly different from democracy even though it has significant affinities to it, for example, in the notion of government by the consent of the governed, formal political equality, inalienable human rights including the right to political participation, accountability of power to the governed and the rule of law ... liberal democracy focuses on the individual whose claims are ultimately placed above the collectivity.

This conforms to a minimalist concept of democracy and posits that the edifice of democracy is premised on rather fragile structures, such as free elections, multipartyism, and civil liberties. From this reading, the concept focuses on democratic equality. The future consolidation of democracy is thus viewed through an emphasis on the procedural and regulatory aspects of the conduct of elections. 
Although the above definitions differ in scope and content a common thread underpins them all: 'Democracy is a form of regime whose legitimacy derives from the principle of popular sovereignty: Namely, that ordinary citizens are equally endowed with the right and ability to govern themselves' (Bratton \& Van de Walle 1997, pp 10-11). The above illustrates that the concept and practice of democracy has a strong political component. What is lacking, as yet, is the realisation that if democracy is to have a positive meaning it must also have an economic content. The support for democracy in the above scenario is, arguably, premised on an appreciation of the political freedoms and equal rights it embodies in Namibia. Its meaning is thus reduced to how well and frequently elections are conducted. Political competition through elections, therefore, endows the Namibian government with a high degree of political legitimacy.

This legitimacy is reinforced by the views of ordinary Namibians of the notion of democracy. Successive surveys reveal that the meaning of democracy to ordinary citizens is based on an appreciation of civil liberties. A survey undertaken some five years ago (Keulder 2002) reveals that 21 per cent of respondents interviewed did not know the meaning of democracy. The same survey also suggests that the most common meaning attached to the concept relates to freedom of speech $(19 \%)$.

These findings are in line with those of a much more recent survey (Bratton \& Cho 2006) which shows that for most respondents in 2000 (67\%) and 2005 (50\%), the notion of democracy is invariably associated with civil and political rights. The meaning of democracy thus refers to a range of attributes that informs political practice. This posits that the meaning of democracy for Namibians is couched within a specific social and historical context, suggesting it is based on its intrinsic value. The exclusionary nature of colonial rule in Namibia means that most of the country's citizens conceived of democracy as ostensibly procedural and inextricably bound to the country's colonial context. Thus, a preliminary conclusion is that both the literature review and the perception of ordinary citizens point to an intrinsic understanding of the notion of democracy.

But post-colonial politics and the meaning of democracy in Namibia should not be reduced to elections and freedom of speech, among other civil liberties. Procedural politics embedded in regular elections is critical, but procedural arrangements are not sufficient to ensure that politics is conducted on democratic lines. This is because even 'Liberal democracy ... connects processes of participation and contestation to a particular kind of economy and a preferred state structure' (Joseph 1997, p 374). ${ }^{3}$ There is thus scope for continuous

3 In instrumental terms, therefore, a fair distribution of economic resources of society 'create a shield for democracy with regards to the rule of law and participation' (Merkel 2004, p 45). 
contestation as we each advance reasons for our preferred concept, meaning and applications of democracy. The argument here is that if democracy is to be consolidated in Namibia, social advancement of people's livelihoods must also enjoy priority.

Henning Melber (2005, p 306) reminds us of the primacy of the above by pointing out that

the anti-colonial movement's proclaimed goals and perspectives were not only about fighting the oppressive and exploitative system of Apartheid colonialism. The liberation struggle was at the same time about creating conditions for a better life after Apartheid - not only in terms of political and human rights but also with regard to the inextricably linked material dimensions to human well being and a decent living of those previously marginalised and excluded from the benefits of wealth created (to a large extent by them).

Not surprisingly, Keulder (2002) notes that Namibians also have an instrumental understanding of democracy informed by, inter alia, socio-economic equity and the provision of public services. To illustrate, more than 90 per cent of respondents to Keulder's survey viewed basic necessities such as shelter, food and water for everyone, jobs for all, and equality in education as being as important as political goods. These findings suggest that the substantive dimensions of democracy are as important as its procedural ones.

What was required at independence and beyond was a process of socioeconomic transformation. Government's ability to meet the social needs of citizens by providing adequate education is demonstrated by the funds committed to education. A United Nations Development Programme (UNDP) report (2004, p 8) states that

Namibia is among the countries in the world that spend the highest share of GDP on public expenditure on education. Since independence, the education sector has consistently received the largest share of the total national budget, currently around $20 \%$, relatively unchanged since $1990 / 91 .^{4}$

4 This section of social services enjoyed special attention after independence for historical reasons. Tom Lodge (1998, p 27) asserts that 'In the northern homeland reserves before independence government service in the 1970s was lower than in relatively much poorer African countries such as Tanzania: in 1975 only 3,645 Africans were enrolled at secondary schools.' It is thus not surprising that $93 \%$ of respondents viewed access to and equality in education as informing their understanding of democracy (Keulder 2002). 
In addition, the Namibian government has made significant strides in its development efforts. It has expanded social services and undertaken considerable land distribution. These efforts play a defining role in determining support for democracy in Namibia and its sustenance.

\section{SUPPORT FOR DEMOCRACY IN NAMIBIA}

A survey conducted by Keulder (2002) revealed that the majority (57\%) of respondents believed that democracy was preferable to any other kind of government (see also Table 1).

Respondents also rejected the concept of one-party rule (37\%), military rule (34\%) and presidential dictatorship (34\%) and believed that the current government should be given time to right the wrongs of the past. The aforementioned is borne out by the degree of economic patience accorded to government by respondents. Bratton \& Cho (2006) illustrate that 52 per cent of respondents are willing to endure current hardship for the sake of future economic improvement.

Table 1

Support for Democracy

Percentage of respondents who believed that 'Democracy is preferable to any other kind of government'

\begin{tabular}{|c|c|c|}
\hline $\mathbf{2 0 0 0}$ & $\mathbf{2 0 0 2}$ & $\mathbf{2 0 0 5}$ \\
\hline 58 & 54 & 57 \\
\hline
\end{tabular}

Source: Bratton \& Cho 2006

Support for democracy is embedded in Namibia's colonial history though colonialism created a paradox: conferring democracy on the white minority while disenfranchising the majority of the populace. Michael Bratton and Nicolas Van der Walle (1997, p 81) assert that in colonial Namibia

settlers reproduced functioning democracies within their own microcosmic enclaves, with features like elections, leadership turnover, loyal opposition, independent courts, and some press freedoms, all reserved exclusively for whites. Thus at the same time that they permitted quite far-reaching measures of political com- 
petition, these regimes proscribed access to the political process by limiting participation.

(See also Du Pisani 2000)

What was, therefore, needed in the aftermath of independence was to expand the political field by allowing, in this instance, the majority the opportunity for political participation. The expansion of the political field is provided for in the Constitution.

Democracy in Namibia is underpinned by the supremacy of the Constitution, commitment to the rule of law, the separation of powers, and a comprehensive and enforceable Bill of Rights, which contains internationally recognised fundamental human rights and freedoms (Erasmus 2000). Table 1 shows that more than 50 per cent of respondents view democracy in Namibia as the best type of government (Bratton \& Cho 2006). By and large, however, the volatility in the support for democracy means that the process of democratic consolidation remains incomplete and fragile. For Keulder \& Wiese (2005, p 3) this unpredictability 'suggests that a significant proportion of Namibians do not support democracy for its intrinsic value, but rather that their support is more instrumental'. ${ }^{5}$ This again produces a caveat: a breakdown of Namibians' support for democracy reveals that political goods, rather than economic conditions, underpin their preference.

Support for elements of democracy again illustrates that choosing leaders through free and fair elections $(82 \%)$ and a general preference for democracy $(56 \%)$ (Keulder \& Wiese 2005, p4) means that political legitimacy is not under threat. On the contrary, it is reinforced by the acceptance and support of democratic rules and institutions. However, the delivery of civil and political rights is not sufficient to sustain the support for democracy or its consolidation. What these variations illustrate is that the Namibian state must play a more active developmental role. ${ }^{6}$ This means expanding state reach throughout the country.

Since independence, the Namibian government has extended social security benefits to all employees, expanded the civil service to absorb those who returned

5 This downward trend in support for democracy based on civil liberties is illustrated by the fact that those liberties were high on the priority list of respondents in 2000 (67\%), whereas in 2005 only 50\% based their support for democracy on these liberties (Bratton \& Cho 2006). A two-pronged explanation may shed light on this shift. Firstly, the downward trend may suggest that people in general have now accepted and support democratic rules and institutions. This has a positive bearing on legitimacy and democratic consolidation. Secondly, it may show that social rights and other economic considerations are now seen as being as important as political rights.

6 Conceptually a developmental state is not only one that can foster growth and development but also 'one whose ideological underpinnings are developmental and one that seriously attempts to deploy its administrative and political resources to the task of economic development' (Tsie 2001, p 65; Ajulu 2001; Tsie 1996). 
from exile, and has resettled 16000 families on state-purchased land (Lodge 1998). ${ }^{7}$ Moreover, it has enacted legislation eliminating legally sanctioned gender inequalities, such as the Married Persons Equality Act of 1996, maternity leave, divorce, and abortion, among others (Bauer 2001). The provision of these social rights will certainly enhance support for any democratic polity. However, conditions that may contribute to deligitimising the democratic system and support for democracy will have to be addressed.

A UNDP country report for 2004 (p 10) notes that 'In 2003, one-third of the population was identified as in need of humanitarian food assistance and the most recent figures show that $40 \%$ of Namibians are living below the income poverty line' (see also NHIES 2004).

The threats to the twin objectives of deepening democracy and achieving sustainable human development in contemporary Namibia (UNDP 2004, p 53) are:

- the high prevalence of HIV and the multiple impacts of AIDS;

- increasing household food insecurity and deepening income poverty and disparities;

- weakening capacities for governance and for delivery of social services.

The UNDP Report (2004, p 54) notes that: 'HIV / AIDS is increasing the vulnerability of households, eroding institutional capacities and is Namibia's most pressing threat directly to the fulfilment of rights to life and health and indirectly to the status of all human rights in the nation'. Other threats to sustainable human development and, by extension, democracy, are increasing household food insecurity and deepening poverty and income disparities. The report cautions that these elements 'could emerge as a threat to Namibia's stability, particularly in the light of AIDS-related worsening of poverty and the historically inequitable distribution of land'. Moreover, ensuring that sustainable human development is achieved demands that 'Efforts must be made to increase household income and agricultural productivity within the context of the AIDS-weakened capacities of families, communities and institutions' (UNDP 2004). These findings correspond with the perception that unemployment (65\%) and food security (53\%) remain the most pressing economic concerns (Bratton \& Cho 2006). This has implication for sustainable human development and could potentially erode democratic gains.

7 More recent figures suggest that the government has been able to settle 1160 families on 66 farms (Werner 2002). 
Addressing these will not only increase the support for democracy but will also improve the Namibian government's political legitimacy. The question to pose is thus: Can the support for democracy be equated with satisfaction with democracy in Namibia?

\section{SATISFACTION WITH DEMOCRACY}

Table 2 shows that there has been a significant increase in satisfaction with democracy in the three years 2000, 2002 and 2005.

Table 2

Satisfaction with Democracy

\begin{tabular}{|l|c|c|c|}
\hline & $\begin{array}{c}2000 \\
\%\end{array}$ & $\begin{array}{c}2002 \\
\%\end{array}$ & $\begin{array}{c}2005 \\
\%\end{array}$ \\
\hline $\begin{array}{l}\text { Overall, how satisfied are you with the way } \\
\text { in which democracy works? }\end{array}$ & 64 & 69 & 69 \\
\hline
\end{tabular}

Source: Bratton \& Cho 2006

Satisfaction with democracy is contingent on the promotion of both intrinsic and instrumental values. Simply put, ordinary people will express satisfaction with a government if they believe it is capable of executing its appointed tasks. For instance, government needs to be able to provide adequate public services, but may also be capable of protecting both the democratic polity and the physical safety and security of its citizens. The ability of the state to perform these multiple tasks is dependent on the trust citizens have in government, in other words, confidence in state institutions. This is because institutions shape the goals that political actors pursue. Tom Lodge (1998) postulates that the goals states pursue are, in turn, influenced by, inter alia, social penetration, which is intimately related to state reach. State reach in this context is defined as

the extent to which a central administrative elite succeeds in incorporating an entire geographical area within territorial boundaries ... it is measured $\ldots$ in terms of the presence of an institutional infrastructure of armed outposts, administrative offices, or service centres.

Bratton 2004, p 3

In simple terms, social penetration refers to the ability of state institutions to link citizens to the state. This not only means that political institutions should be 
responsive to citizens' needs, but that citizens' political attitudes should reflect their trust in government institutions. ${ }^{8}$

In Namibia, the perception of government's capacity to solve problems has shown a slight increase from 24 per cent in 2002 to 36 per cent in 2003 (Keulder \& Wiese 2005). Over all, however, the low percentage of respondents who express confidence in government institutions suggests poor levels of satisfaction with the political regime as a whole. This reading represents, however, an incomplete picture of the degree of satisfaction the political regime in Namibia enjoys. To measure this level of satisfaction one must look at the delivery of political goods.

As illustrated elsewhere, both the understanding of and support for democracy in Namibia is shaped by the extent to which government can guarantee a basket of political commodities. Indeed, in Namibia, the delivery of political goods is essential to shaping the perception that citizens are satisfied with the political regime as a whole. Satisfaction with democracy can be measured by looking at political freedoms, elections, and the performance of elected officials. To reinforce the contention that instrumental considerations play a defining role in measuring the support for democracy in Namibia, it is crucial to look at political freedoms. A notable element of the survey results is that 'Most Namibians seem to think that the current regime is better at providing and securing basic political liberties: freedom of speech (92\%), freedom to join political organisations $(92 \%)$, and freedom to vote (91\%)' (Keulder \& Wiese 2005, p 8). These results suggest that Namibians think of government performance first and foremost in political terms. This does not suggest that instrumental considerations are not important. Indeed, economic growth and improved social welfare, two of the variables used to explain how satisfied people are with the delivery of economic goods, have considerable implications for the stability and quality of a democracy.

Namibians are increasingly satisfied with macro-economic conditions in the country. In 2000, 42 per cent indicated satisfaction and the level rose to 57 per cent in 2002 and 59 per cent in 2005 (Bratton \& Cho 2006). These positive ratings are reinforced by the evaluation of the way in which government is managing the economy. Keulder \& Wiese's survey results $(2005, \mathrm{p} 15)$ show that 'The areas in which government's performance is seen to have increased the most from 2002 to 2003 are the following: narrowing the income gap ( 7 per cent), improving basic health care services ( 4 per cent) and addressing educational needs (4 per cent).' The above findings suggest that government has been able to improve its ability

8 Satisfaction with democracy is undermined by official corruption. In Namibia, the perception that corruption is increasing is confirmed by the upswing in levels of corruption since 2000. Survey results show that perceived corruption increased from 25\% in 2000 to $30 \%$ in 2002 and 35\% in 2005 (Bratton \& Cho 2006). While this does not necessarily have an impact on satisfaction with democracy, it does have a bearing on state legitimacy. 
on the economic management front, while provisions for the social sector seem to reinforce the contention that support for democracy is also based on instrumental considerations. Moreover, it also illustrate that satisfaction with democracy, in instrumental terms, is ostensibly measured by reference to the condition of the national economy.

\section{CONCLUSION}

This paper has argued that, at face value, intrinsic support for democracy in Namibia superseded instrumental considerations. Indeed, the provision of political goods such as civil liberties, voting rights, and equal treatment under the law, influences the perception that citizens are satisfied with democracy. This implies that government performance is invariably measured by the delivery of political goods. This observation posits that the delivery of political goods is crucial for the consolidation of democracy in the country. In simple terms, the regime in Namibia has been able to legitimate itself by delivering political goods. Simply put, the enjoyment of civil liberties remains a critical determinant of satisfaction with and support for democracy.

However, if it is true that people measure government support holistically, then it is critical that we also review economic explanations of satisfaction with democracy. Such explanations are generally reduced to the condition of the national economy. So far, Namibians are positive about the economy, but the government faces a number of developmental challenges. Namibia's development continues to be undermined by, among others, the high prevalence and multiple impact of HIV/AIDS, increasing household food insecurity, deepening poverty, and a deteriorating capacity for governance and delivery of social services.

The above illustrates that the consolidation of democracy in Namibia is threatened and hampered by persistent poverty, unemployment and the scourge of HIV / AIDS. Thus, when analysing the state of democracy in the country, the focus should be on the prospects for consolidation rather than the mere physical attributes of the democratic regime. This is not to say that these attributes are unimportant in themselves, but what must be explained is how they contribute to deepening democracy.

Ultimately, therefore, support and satisfaction with democracy is and should be measured by satisfaction with key aspects of the elected regime. The above illustrates that support for democracy as a preferred system of government supersedes satisfaction with the way it actually works. More fundamentally, it illustrates that intrinsic support for democracy does not necessarily exceed instrumental considerations. This reinforces my contention that in Namibia government performance is viewed in holistic as opposed to intrinsic or instrumental terms. 


\section{- REFERENCES}

Ajulu, R. 2001. 'Thabo Mbeki's African Renaissance in a Globalising World Economy: The Struggle for the Soul of the Continent'. Review of African Political Economy 28.

Ake, C. 1993. 'The Unique Case of African Democracy'. International Affairs 69(2). . 2003. The Feasibility of Democracy in Africa (2nd ed). Senegal: CODESRIA.

Alence, R. 2004. 'Political Institutions and Developmental Governance in subSaharan Africa'. Journal of Modern African Studies 42(2).

Bauer, G. 2001. 'Namibia the First Decade of Independence: How Democratic?' Journal of Southern African Studies 27(1).

Bratton, M. 2004. State Building and Democratization in Sub-Saharan Africa: Forwards, Backwards or Together? Afrobarometer Paper no 43. Cape Town: IDASA.

— \& N Van de Walle. 1997. Democratic Experiments in Africa: Regime Transition in Comparative Perspective. Cambridge: Cambridge University Press.

— \& R Mattes. 2001. 'Support for Democracy in Africa: Intrinsic or Instrumental'. British Journal of Political Science 31.

\& W Cho. 2006. Where is Africa Going? View from Below: A Compendium of Trends in Public Opinion in 12 African Countries. Afrobarometer Paper no 60. Cape Town: IDASA.

Du Pisani, A. 2000. 'State and Society Under South African Rule'. In C Keulder (ed). State, Society and Democracy: A Reader in Namibian Politics. Windhoek: Gamsberg Macmillan.

Erasmus, G. 2000. 'The Constitution: Its Impact on Namibian Statehood and Politics'. In C Keulder (ed). State, Society and Democracy: A Reader in Namibian Politics. Windhoek: Gamsberg Macmillan.

Good, K. 2001.The Liberal Model and Africa: Elites against Democracy. London: Palgrave.

Huntington, S. 1991. The Third Wave: Democratisation in the Late Twentieth Century. Norman and London: University of Oklahoma Press.

Joseph, R. 1997. 'Democratization in Africa after 1989: Comparative and Theoretical Perspectives'. Comparative Politics 29(3).

Keulder, C. 2002. Public Opinion and the Consolidation of Democracy in Namibia. Afrobarometer Paper no 15. Cape Town: IDASA.

\& T Wiese. 2005. Democracy without Democrats? Results from the 2003 Afrobarometer Survey in Namibia. Afrobarometer Paper no 47. Cape Town: IDASA.

Lodge, T. 1998. 'The Post-Colonial State in Southern Africa'. Commonwealth and Comparative Politics 36(1).

Melber, H. 2005. 'Namibia's Post-Colonial Socio-Economic (Non-) Transformation: Business As Usual?' Nord-Süd Aktuell 3(4). 
Merkel, W. 2004. 'Embedded and Defective Democracies'. Democratization 11(5).

National Planning Commission. 2004. National Housing Income and Expenditure Survey, 2004. Windhoek: Government Printers.

Schmitter, P \& T Karl. 1996. 'What Democracy Is ... And Is Not'. In L Diamond \& M Plattner (eds). The Global Resurgence of Democracy (2nd ed). Baltimore: Johns Hopkins University Press.

Southall, R. 2003. 'Democracy in Southern Africa: Moving Beyond a Difficult Legacy'. Review of African Political Economy 96.

Tsie, B. 1996. 'The Political Context of Botswana's Development Performance'. Journal of Southern African Studies 22(4).

- 2001. 'Democratisation and Governance'. In R de Villiers \& K Lambrechts (eds). The IGD guide to the Southern African Development Community. Johannesburg: Institute for Global Dialogue.

United Nations Development Programme (UNDP). 2004. United Nations Namibia: Common Country Assessment 2004. Windhoek: UNDP Namibia.

Van de Walle, N. 2002. 'Elections Without Democracy: Africa's Range of Regimes'. Journal of Democracy 13(3).

Werner, W. 2002. The Current State of Land Reform in Namibia: Some Facts and Figures. Background Paper Prepared for the Conference on Land Hosted by the Namibian Agricultural Union, Windhoek, February.

Wiseman, J. 1999. 'The Continuing Case for Demo-Optimism in Africa'. Democratization 6(2). 